\title{
The effects of rhizome size, planting density and plastic mulch on the growth and dry matter yield of miscanthus over three seasons
}

D L Easson, E G A Forbes, A R McCracken

Agri- Food and Biosciences Institute, Northern Ireland, United Kingdom

Email: lindsay.easson@afbini.gov.uk

Introduction Miscanthus (Miscanthus x gigantaeus), a C4 perennial grass from the Far East, is being increasingly widely grown in the British Isles as a biomass crop with an annual harvest. Following establishment by planting rhizome sections into cultivated ground it can take four to five years for the crop to reach its maximum level of productivity. An experiment is in progress in Northern Ireland into the use of degradable plastic mulch to accelerate the development of the crop, and its interaction with rhizome size and density at planting. The first three years of the study are described in this paper.

Materials and methods Rhizomes from miscanthus planted in 2003 were harvested in April 2007 and stored at $3^{\circ} \mathrm{C}$. The rhizome pieces were sorted into three size fractions which averaged weights of $26 \mathrm{~g}, 74 \mathrm{~g}$ and $204 \mathrm{~g}$. Experimental sites at Hillsborough and Loughgall were prepared by conventional cultivation and rhizomes planted by hand in early May in shallow furrows in plots $10 \mathrm{~m} \times 7.5 \mathrm{~m}$ at densities equivalent to $450 \mathrm{~kg}, 1350 \mathrm{~kg}$ and $4050 \mathrm{~kg}$ per hectare for each size fraction. The rhizomes were covered with soil to a depth of about $7.5 \mathrm{~cm}$ and the herbicide pendimethalin applied at 2.5 litres/ha. The four randomised blocks at each site comprised main plots with and without bio-degradable plastic mulch, applied shortly after planting with a single row mulch layer supplied by SAMCO Agricultural Manufacturing Ltd, and nine size $x$ density sub-plots. Regular counts were taken of the number of shoots, and of shoot height, over the 2007, 2008 and 2009 seasons. DM yield above ground was assessed by sampling in the late autumn and again in the spring before the plots were harvested. Data was statistically analysed as a split-split-plot randomised block design.

Results and discussion The increase in the number of shoots as the rhizome size was reduced from $204 \mathrm{~g}$ to $26 \mathrm{~g}$ reported by Easson et al (2008) for the first year of this study was maintained into the $2^{\text {nd }}$ and $3^{\text {rd }}$ years (Table 1 ), along with an overall doubling of the number of shoots in the $3^{\text {rd }}$ season compared with the first season. The increased number of shoots resulted in significantly higher DM yields with decreasing rhizome size at planting at all harvest dates.

Table 1 Main treatment effects of rhizome size, planting density and plastic mulch treatment at planting on the growth and yield of miscanthus in the first three seasons (mean of two sites)

\begin{tabular}{|c|c|c|c|c|c|c|c|c|c|}
\hline & \multicolumn{3}{|c|}{ Shoot numbers per hectare ('000s) } & \multicolumn{2}{|c|}{ Crop height $(\mathrm{cm})$} & \multicolumn{3}{|c|}{ DM yield (t/ha) } \\
\hline & & Oct ' 07 & Oct '08 & Oct'09 & Oct '08 & Oct '09 & Mar '08 & Nov '08 & Mar '09 \\
\hline Rhizome & $26 \mathrm{~g}$ & 140 & 222 & 309 & 187 & 234 & 0.81 & 9.28 & 6.07 \\
\hline \multirow[t]{2}{*}{ size } & $74 \mathrm{~g}$ & 99 & 166 & 234 & 184 & 228 & 0.65 & 7.79 & 5.27 \\
\hline & $204 \mathrm{~g}$ & 69 & 99 & 130 & 182 & 221 & 0.44 & 5.03 & 2.95 \\
\hline \multicolumn{2}{|c|}{ 1.s.d. $(P=0.05,94 \mathrm{df})$} & 12.6 & 14.8 & 22.5 & 3.3 & 9.7 & 0.126 & 1.636 & 1.215 \\
\hline Density & 450 & 39 & 63 & 90 & 160 & 201 & 0.19 & 3.59 & 2.09 \\
\hline \multirow[t]{2}{*}{$\mathrm{kg} / \mathrm{ha}$} & 1350 & 80 & 151 & 215 & 179 & 227 & 0.43 & 6.51 & 3.94 \\
\hline & 4050 & 189 & 273 & 368 & 214 & 256 & 1.27 & 12.00 & 8.25 \\
\hline \multicolumn{2}{|c|}{ 1.s.d. $(P=0.05,94 \mathrm{df})$} & 12.6 & 14.8 & 22.5 & 3.3 & 9.7 & 0.126 & 1.636 & 1.215 \\
\hline \multirow[t]{2}{*}{ Mulch } & without & 67 & 134 & 196 & 180 & 227 & 0.47 & 5.98 & 3.97 \\
\hline & with & 131 & 191 & 253 & 189 & 229 & 0.79 & 8.75 & 5.55 \\
\hline \multicolumn{2}{|c|}{ 1.s.d. $(P=0.05,6 \mathrm{df})$} & 12.9 & 23.2 & 35.0 & 5.7 & 25.6 & 0.108 & 1.571 & 1.422 \\
\hline \multicolumn{2}{|l|}{ Mean } & 103 & 162 & 224 & 185 & 228 & 0.63 & 7.37 & 4.76 \\
\hline
\end{tabular}

The number of shoots also increased significantly at higher planting densities so that the number of shoots and the DM yield almost doubled with each threefold increase in planting rate, the ratio remaining similar into the $3^{\text {rd }}$ season. Crop height increased significantly with increased density. The use of mulch increased the number of shoots in the first season by $96 \%$, and this effect carried on into the $2^{\text {nd }}$ and $3^{\text {rd }}$ seasons in which shoot numbers were higher by $48 \%$ and $38 \%$ respectively. Crop height was significantly increased in the $2^{\text {nd }}$ season, but not the $3^{\text {rd }}$. Crop yield increased by $70 \%, 46 \%$ and $40 \%$ at the March and November 2008 and March 2009 sampling dates respectively. Interaction effects between the use of mulch, rhizome size and planting density were relatively small. The highest yields were therefore from the $24 \mathrm{~g}$ rhizome size planted at high density with the use of plastic mulch with yields of $17.8 \mathrm{tDM} / \mathrm{ha}$ and $10.7 \mathrm{tDM} / \mathrm{ha}$ in November 2008 and March 2009 respectively. The results from these harvest dates reveal over-winter losses from leaf fall and the loss of upper internodes of $30 \%$ to $40 \%$. Under Northern Ireland conditions little drying of the crop took place over winter and at the March harvest date in both 2008 and 2009 the stem was about 50\% DM.

Conclusions The use of degradable plastic mulch at planting accelerated the early development of miscanthus, with the benefits continuing into subsequent years. Within the ranges of weights used in this experiment dividing rhizomes into smaller sections for planting achieved higher shoot numbers and yields over the first two seasons.

Acknowledgement This work was funded by the Department of Agriculture and Rural Development

Easson, D.L., McCracken, A.R., Forbes, E.G.A. and Moore, P.J. Agricultural Research Forum. March 2009, 58 